\title{
Profitability Analysis of Small ruminants (Goat and Sheep) Production in Rural Communities of Ghana
}

\author{
Opoku Agyeman ${ }^{1, a}$, Liu Shuai ${ }^{1, b, *}$, Yagbasuah Maada Baion ${ }^{1}$ and Charles Kwasi Antwi²,c \\ ${ }^{1}$ College of Economics and Management, Jilin Agricultural University, Changchun, 130118, China \\ ${ }^{2}$ Department of Consumer and Food Science, University of Pretoria, Pretoria, South Africa \\ a.oagyeman85@gmail.com,b.liushuai@jlau.edu.cn,c.charlesantwi390@gmail.com \\ *corresponding author
}

Keywords: Small Ruminants, Livestock, Profitability, Revenue-Cost Ratio, Ghana.

\begin{abstract}
Agriculture is the main driving force of rural economies with livestock, especially small ruminants' making an important contribution. This study sought to analyse the profitability of small ruminants (goat and sheep) production in rural communities. Primary data from questionnaire administration and secondary data were used. A budgetary analytical technique was used for the analysis to estimate the profit of the enterprises. The study found that small ruminants (goat and sheep) production is profitable and viable with a revenue-cost ratio of 1.86. Therefore, government and non-governmental organizations should support small ruminant producers with credit, adequate training, and make it a major component of farming to curb unemployment.
\end{abstract}

\section{Introduction}

\subsection{Background}

The globalization of Agriculture has expanded market opportunities for livestock producers ${ }^{\text {[1] }}$. Livestock makes an important contribution to most economies; they serve as food, provide security, enhance crop production, and generate cash for the rural and urban population ${ }^{[2]}$. Despite the numerous importance of livestock especially small ruminants, its production is still considered as a way of life and not a business. With the realization of the need to increase the animal source of protein in the diet of the average Ghanaian, it is becoming increasingly important to adopt efficient methods to improve animal production. This will involve changes in management husbandry practices and the provision of adequate and appropriate health schemes ${ }^{[3]}$.

Goat meat is a delicacy in several of the Ghanaian communities, yet protein deficiency is widespread in low-income groups in Ghana ${ }^{[4]}$.

It should be possible under proper extension education in the care and management of sheep and goats to increase the number of these species and improve upon the level of animal protein consumption. The human population in less developed countries is increasing rapidly and more food 
is needed to feed this great number of people. Also, the standard of living of some section of the population is rising and there is more per capita demand for meat, milk, and other animal products.

It is therefore important to increase the population of small ruminants in this country to meet rising demand. According to Okorie, it is not correct to maintain that the production of small ruminants is not economical, but the problem lies in the lack of efficient techniques of management under an improved system ${ }^{[5]}$.

Farmers in the Ashanti Region of Ghana give little recognition to sheep and goat production. They consider it a way of life and not as a business. Unfortunately, farmers in the area appear to have little or no information on the profitability of small ruminant production as well as its contribution to household income. Koney reported that farmers will need to be motivated by increase returns from their animals before they will make a significant investment in this area ${ }^{[3]}$. In this sense, this research aimed to determine how profitable small ruminant production is in rural communities. It was hypothesized that livestock, especially small ruminant production is a major source of income for both rural and urban dwellers and has the possibility of reducing poverty. The findings of this research would serve as a basis for both farmers and policymakers to make their independent judgement and decide whether to commit more resources to the production of small ruminants or not.

\section{Literature Review and Conceptual Framework}

According to Liučvaitiene et al, profit is the difference between total revenue and total cost. He also explained accounting profit as total revenue less all-explicit cost incurred ${ }^{[6]}$. The term revenue refers to the receipts obtained by the farmer from the sales of certain quantities of farm products at various prices ${ }^{[7]}$. Total revenue refers to the total amount of money that the farmer receives from the sales of his products.

Also, Adegeye and Dittoh stated cost refers to the value of the inputs used in production ${ }^{[8]}$. Cramer and Jensen distinguished two general groups of costs ${ }^{[9]}$ :

- Explicit costs: are costs incurred when money is spent to hire labor or feed.

- Implicit costs: are incurred by using any resource for which there is no cash outlay during the period that the resource was being used.

Steele mentioned that one reason why goats should be kept even in preference to larger animals such as cattle is their low purchase price ${ }^{[10]}$. They reduce the risk of losses to owners because they are relatively affordable and easy to replace. The cost of sheep is much less than the cost of a cow and a smallholder may be able to afford to have one or two ewes but not a cow ${ }^{[11]}$. Most intensive management of livestock involves high costs resulting from high labour costs, expensive feed, or large investment in one of the inputs such as land or animals ${ }^{[10]}$. According to Flanders and Gillespie, the initial costs of sheep production are low. The enterprise does not require expensive housing or equipment ${ }^{[12]}$.

Wilson observed that animals do not only serve as human food buffers in times of crop shortage but also as temporary and long-term stores of wealth ${ }^{[13]}$. Haruna and Nazifatu in their study on the analytical study of house income of livestock production in the Tamale Municipality revealed that when variable rainfall reduces yield, households fall on livestock to meet their needs and cater for other expenses ${ }^{[14]}$. In some African countries, livestock contributes roughly $80 \%$ of cash income and crop farming systems. As livestock production increases, smallholder farmers will increasingly walk away from poverty ${ }^{[15]}$.

Gatenby argues that investment in sheep avoids losses due to high inflation rates found in the unstable economics of many less developed countries ${ }^{[11]}$. Sheep can be sold quickly when cash is needed. Goats are important means by which farmers earn supplementary income and accumulate capital ${ }^{[16]}$. 
Gapalakrishman et al, remarked that farmers who are into sheep production had relief or insurance in the event of crises arising from crop failure ${ }^{[17]}$. Sheep and goats are normally sold during the dry season when the farmer is trapped for cash ${ }^{[14]}$. According to Opoku-Mensah, livestock is not only viewed as farmers' bank but also, they are used for traditional sacrifices, dowry, gifts, festivities as well as wealth in promotion of family prestige ${ }^{[18]}$.

The first Medium-term Development programme (1997-2000) of Ghana-Vision 2020 stated the problems of livestock production to include poor access to improve stock, the prevalence of disease especially Anthrax and Brucellosis, insufficient pasture for grazing animals especially in the dry season, high cost of processed animal feeds and conflict between crop and livestock farmers over land use ${ }^{[19]}$.

In the tropics, various types of housing and confinement exist, which vary according to the type of animal, climate, production purpose, and socio-economic environment ${ }^{[20]}$. According to Steele, a few different systems of ruminant production exist including the Extensive system, Intensive system, and Semi-intensive system ${ }^{[10]}$.

\section{Materials and Methods}

The study area, Atwima Mponua District in the Ashanti Region of Ghana lies between longitude 2000 ' $\mathrm{W}$ and 2032' $\mathrm{W}$ and latitude 6032 ' $\mathrm{N}$ and $6075^{\prime} \mathrm{N}$ of the equator. Ecologically the district lies in the semi-equatorial forest zone marked by double maxima rainfall seasons. The annual average rainfall is about $1,700 \mathrm{~mm}-1,850 \mathrm{~mm}$ per year.

This research aims to analyse how profitable small ruminant production is in rural communities. To do so, data was obtained from both primary and secondary sources. It was also necessary to integrate both quantitative and qualitative tools to focus on the mechanisms of livestock production in the research area. Aspects such as the cost of small ruminant's production and prices of inputs and animals were evaluated quantitatively, other elements, such as systems of small ruminant's production and constraint to small ruminant's production were assessed through qualitative indicators.

\subsection{Data Collection}

Primary data was collected by the administration of questionnaire to small ruminant producers while secondary data was obtained by analysis consisted of searching and reviewing technical documentation of the Animal Research Institute of the Council for Scientific and Industrial Research (ARI-CSIR), Ministry of Food and Agriculture (MoFA), public library, the internet, and journals.

Personal observation was made of the locality, people, and livestock housing structures. These observations were made during field trips to conduct interviews and this provided a more realistic picture of the livestock situation.

Both purposive and simple random sampling techniques were used in the data collection. Purposive sampling was used to select farmers who rear small ruminants. Simple random sampling was employed to select the respondents. A sample size of 100 small ruminant farmers was used from three randomly selected communities in the Atwima Mponua District. These communities are Nyinahin, Atwima Kotokuom, and Ntoboroso.

\subsection{Method of Data Analysis}

The budgetary analytical technique was used to estimate profit. The budgetary analysis was based on cost and returns data of small ruminant owners. Profit was then estimated as:

$$
\pi=T R-T C
$$




$$
\begin{array}{r}
\pi=T R-F C-V C \\
T R=P Q
\end{array}
$$

Where $\pi$ represents the profit, TR is total revenue, TC is the total cost, FC is fixed cost, VC is variable costs, $\mathrm{P}$ is the price of animals and $\mathrm{Q}$ represents the number of animals.

For Total Cost (TC), the fixed costs incurred are land and housing (Note: All respondents keep their animals in their family houses, therefore, paid nothing for land. Most respondents housed their animals using a simple housing structure built with mortar and wood roofed with zinc sheets and thatch) and the variable cost was mainly the cost of feeding, labour, medication, and cost of the initial stock of animals.

$$
T C=F C+V C+D
$$

Where TC represents total cost, FC is fixed cost, and D represents a depreciation of fixed asset (housing).

A depreciation value of the housing structure was calculated using a salvage value of zero since producers will not sell the house after use. The straight-line method was used to calculate depreciation as follows:

$$
D=\frac{O V-S V}{E}
$$

Where D represents the Annual depreciation charge, OV is the Original value of an asset, SV is the Salvage value of the asset, and E represents the Expected lifespan of assets.

The profitability analysis was based on a one-year production period. Profitability was estimated using the Revenue-cost ratio $(\mathrm{R} / \mathrm{C})$ in equation (6):

$$
R / C=\frac{\sum R 1}{\sum C 1}
$$

Where $\sum \mathrm{R}_{1}$ represents the summation of total revenue and $\sum \mathrm{C}_{1}$ is the summation of the total cost.

\section{Results and Discussion}

It was observed that small ruminant production in the Atwima Mponua District is male-dominated (88\%) and this confirms findings of Agyeman et al, who stated that small ruminants are under the responsibility of the landlord of the compound which limits the effort spend on their handling by individual household member especially women ${ }^{[21]}$. The high number of males was probably because males are regarded as the head of the family and hence have dominance over the productive assets and the women are the caretakers.

Also, production and ownership of small ruminants in the study area have no restriction on age and religion and affect the production of small ruminants positively to fuel the meat industry.

About $63 \%$ of the farmers had no formal education and this will hinder the adoption of innovations for increased production to impact positively on the income and standard of living of farmers. This falls in line with Adams and Ohene-Yankyera that high illiteracy is a hindrance and could greatly retard the assimilation of new and appropriate technology ${ }^{[22]}$.

It was observed that flock size rarely exceeded 40 and this confirms that farmers in these areas do not rear ruminants on a commercial basis but on a subsistence basis which attest to what Ampaire and Rothschild stated that the nature of livestock rearing in rural households are under subsistence farming and livestock rearing is not considered to be a business enterprise ${ }^{[23]}$. 
Animals kept under a semi-intensive system get enough space to exercise and search for additional feed aside from feed supplements, the farmers confirmed. Some $(16.7 \%)$ of the farmers practiced extensive systems (outdoor throughout) of production. In this system, the farmer does not spend much in production and the animals have adequate access to grasses and feed of their choice. However, the animals were exposed to some threats such as high mortality, snake bites, and low growth rate.

Only a few farmers (5\%) have been able to keep their animals in confinement (intensive system) and it helps limit public disturbances from ruminants, especially goats.

\subsection{Cost of Small Ruminants Production}

Feeding, housing, and medication constitute the main cost in small ruminants' production (table 1). The cost of small ruminants' production per annum was calculated based on the respondents' system of keeping animals. That is feeding, housing and medication costs are the same for both goats and sheep. This justifies why the respondents in rural communities do not consider small ruminants production as a business.

Feeding carries the greatest proportion with an average cost of GH\$195.01 per farmer, for an average flock size of 16 sheep and goats each. The average cost of rearing sheep per farmer per annum is GH\$289.64 while the average cost of rearing goats per annum is GH\$279.44. The average cost of rearing one sheep in a year is GH\$18.10 while the average cost of rearing one goat in a year is GH\$17.47. The main cost of medication is the cost of veterinary services because most farmers treat their animals through veterinary services. The study observed that some respondents kept both goats and sheep in one pen while others divided one pen into two.

Table 1: Cost of Small Ruminants’ Production Per Annum (GHథ)

\begin{tabular}{|c|c|c|c|c|c|}
\hline \multirow{2}{*}{ Area } & \multicolumn{2}{|c|}{ Cost of Initial stock } & \multirow{2}{*}{ Feeding } & \multirow{2}{*}{ Housing } & \multirow{2}{*}{ Medication } \\
\hline & Sheep & Goats & & & \\
\hline Nyinahin & 70.50 & 39.00 & $2,530.95$ & 952.20 & 234.50 \\
\hline $\begin{array}{l}\text { Atwima } \\
\text { Kotokuom } \\
\text { Ntoboroso }\end{array}$ & $\begin{array}{l}158.00 \\
778.80\end{array}$ & $\begin{array}{r}49.00 \\
307.35\end{array}$ & $\begin{array}{l}3,915.84 \\
5,253.96\end{array}$ & $1,503.40$ & $\begin{array}{l}248.56 \\
358.97\end{array}$ \\
\hline Total & $1,007.30$ & 395.35 & $11,700.75$ & 3646.10 & 842.03 \\
\hline $\begin{array}{c}\text { Average } \\
\text { Depreciation }\end{array}$ & 16.79 & 6.59 & 195.01 & $\begin{array}{l}60.77 \\
3.038\end{array}$ & 14.03 \\
\hline
\end{tabular}

\subsection{Revenue from Small Ruminants’ Production}

The average revenue from small ruminants’ production is GH\$1,055.67 per farmer per annum, that is, average revenues of GH\$ 676.5 and $\mathrm{GH} \$ 379.17$ from sheep and goats’ enterprises, respectively (table 2). Revenue from sheep constitutes $64.0 \%$ of total revenue while the revenue from goats constitutes $36.0 \%$.

Table 2: Total Revenue from Ruminants Production (GH\$)

\begin{tabular}{ccc}
\hline Area & Sheep & Goat \\
\hline Nyinahin & 18,425 & 5,495 \\
Atwima Kotokuom & 11,330 & 6,860 \\
Ntoboroso & 10,835 & 10,395 \\
\hline
\end{tabular}




\subsection{Profit and Profitability}

The profitability of a small ruminant enterprise was estimated using the revenue-cost ratio from equation (6):

$$
\begin{array}{r}
R / C=\frac{\sum R 1}{\sum C 1} \\
\mathrm{R} / \mathrm{C}=\frac{1,055.67}{569.08}=1.85
\end{array}
$$

Average revenue less average cost gives an annual net profit of; GH $₫ 386.86$ from sheep and GH\$99.72 from goats.

$$
\begin{array}{r}
\text { Revenue-cost ratio }=\frac{\text { Average } \text { Revenue }}{\text { Average } \text { Cost }} \\
\text { For sheep }=\frac{676.5}{289.64}=2.33 \\
\text { For goats }=\frac{379.17}{279.44}=1.36 \\
\text { Overall ratio }=\frac{(676.5+379.17)}{(289.64+279.44)}=1.86
\end{array}
$$

\section{Conclusion and Policy Implication}

On the whole, small ruminant production is profitable. Although farmers give little recognition to small ruminants rearing, farmers obtain income from the sales of their animals to supplement other sources of income. Income from small ruminants is used to buy food during lean seasons and to pay school fees. Sheep and goat meat form an important component of the diet of many people. Finally, a revenue-cost ratio of 1.86 (with ratios of 2.33 for sheep and 1.36 for goats) from small ruminants' production can be profitable if farmers will give a business-like attitude towards the production and management of small ruminants (a lower ratio means higher profit).

The study also recommends that; both governmental and non-governmental organizations should make available credit facilities to help small ruminants producers solve feeding problems, small ruminants rearing should be made a major component of farming to solve the problem of unemployment, and farmers should be given adequate training on management practices to improve upon productivity through effective veterinary and extension services.

\section{References}

[1] G. Murphy, J. Scanga, K. Belk, G. Smith, D. Pendell, and D. Morris, "Animal identification systems in North America," The professional animal scientist, vol. 24, no. 4, pp. 277-286, 2008.

[2] C. Seré, H. Steinfeld, and J. Groenewold, World livestock production systems. Food and Agriculture Organization of the United Nations, 1996. 
[3] E. Koney, Livestock production and health in Ghana. Advent press, 1992.

[4] J. Dzakuma, Food animals in Ghana-under-utilized resources. GUP, 1989.

[5] J. Okorie, A guide to livestock production in Nigeria. Macmillan, 1983.

[6] A. Liučvaitienè, K. Peleckis, N. Slavinskaitè, and T. Limba, "Theoretical models of business competitiveness: formation and evaluation," Strategic Management Review, vol. 1, no. 1, pp. 31-44, 2013.

[7] A. Sadhu and A. Singh, "Fundamentals of Agricultural Economics," 1983.

[8] A. Adegeye and J. Dittoh, "Essentials of agricultural economics impact," Ibadan: Publishers Nigeria Ltd, 1985.

[9] G. L. Cramer, C. W. Jensen, and D. D. Southgate Jr, "Agricultural Economics and Agribusiness, Jhon Wiley \& Sons," Inc. New York, 1994.

[10] M. Steele, "The tropical agriculturalist: goats," The tropical agriculturalist: goats., 1996.

[11] R. Gatenby, "Sheep: The tropical Agriculturalist, London and MACMILLAN educational Ltd," 1991: ACCT.

[12] F. Flanders and J. R. Gillespie, Modern livestock \& poultry production. Cengage Learning, 2015.

[13] R. Wilson, "The Tropical Agriculturalist, Livestock production systems, Distribution and Importance of livestock in the tropics," London: CTAMacmillan, vol. 5, 1995.

[14] I. a. N. Haruna, M. , "Analytical study of household income from livestock production in the Tamale Municipality. ," BSc. Dissertation. Department of agricultural economics and extension, University for Development Studies, Tamale, Ghana. (Unpublished dissertation). , p. 36, 2002.

[15] A. T. Awuni, "The contribution of livestock production to household food and cash security: The case of the Bolgatanga Municipality in the Upper East Region of Ghana.,". BSc. Dissertation. Department of agricultural economics and extension, University for Development Studies, Tamale, Ghana.(Unpublished), pp. 14 - 23, 2003.

[16] W. J. A. Payne and R. T. Wilson, An introduction to animal husbandry in the tropics (no. Edn 5). Blackwell Science, 1999.

[17] C. Gopalakrishnan and G. M. M. Lal, Livestock and poultry enterprises for rural development. Vikas Publishing House, 1993.

[18] D. Opoku-Mensah, The role of small ruminants in rural household food security in the Tolon-Kumbungu District of the Northern Region. BSc. Dissertation. Department of agricultural economics and extension, University for Development Studies, Tamale, Ghana.(Unpublished), 2004.

[19] G. V. 2020, The first medium-term development plan. Government of Ghana national development planning commission. 1997.

[20] R. E. Taylor, Scientific farm animal production: An introduction to animal science (no. Ed. 5). Prentice-Hall International, Inc., 1995.

[21] O. Agyeman, J. Naandam, and S. Laar, "PROSPECTS AND CONSTRAINTS OF ANIMAL IDENTIFICATION IN TOLON-KUMBUNGU DISTRICT OF GHANA," GHANA ANIMAL SCIENCE ASSOCIATION, p. 423, 2014.

[22] F. Adams and K. Ohene-Yankyera, "Socio-economic characteristics of subsistent small ruminant farmers in three regions of northern Ghana," Asian Journal of applied science and engineering, vol. 3, no. 3, pp. 351-364, 2014.

[23] A. Ampaire and M. F. Rothschild, "Pigs, goats and chickens for rural development: small holder farmer's experience in Uganda," Livestock Research for Rural Development, vol. 22, no. 6, p. 1, 2010. 